Bangladesh J. Zool. 41(2): 165-172, 2013

\title{
FECUNDITY AND GONADO SOMATIC INDEX OF GANGETIC MUD EEL, MONOPTERUS CUCHIA (HAMILTON, 1822)
}

\author{
Binay K. Chakraborty, S. A. Azad, B. Barman ${ }^{1}$ and A.M.O. Faruque \\ Matshya Bhaban, Department of Fisheries, Ramna, Dhaka-1000, Bangladesh
}

\begin{abstract}
The gonado-somatic index (GSI) and fecundity of Gangetic mud eels Monopterus cuchia (Hamilton, 1822) were investigated during January to December, 2010 at Sherpur, Bangladesh. Highest GSI value was found in the month of June and the values began to fall gradually from July to December in both sexes. The fecundity ranged from $458.0 \pm 31.22$ to $1116.0 \pm 11.31$ in 62 samples having a total length of $54.25 \pm 1.71$ to $66.05 \pm 0.71 \mathrm{~cm}$, body weight from $256.33 \pm 45.14$ to $492.50 \pm 2.50 \mathrm{~g}$ and gonad weight from $21.32 \pm 4.48$ to $55.90 \pm 0.98$ g. The relationships between body length and fecundity was found to be polynomial of second order of body weight and was expressed as: $\mathrm{Y}=0.2683 \mathrm{X}^{2}$ $1.9383 \mathrm{X}+370.72$. The regression equation established for fecundity on total body weight was $Y=454.37 \mathrm{X}-692.8$. The regression equation established for fecundity on total gonad weight was $\mathrm{Y}=19.602 \mathrm{X}-27.546$. The above equation showed that the relationships between fecundity and total weight was curvilinear. A highly significant $(\mathrm{P}<0.01)$ linear relationship was found to exist between fecundity and gonadal weight.
\end{abstract}

Key words: Gonado-somatic-index (GSI), Fecundity, Mud eel, Monopterus cuchia

\section{INTRODUCTION}

The Gangetic mud eel, Monopterus cuchia is a freshwater air breathing, swamp mud eel is locally known as cuchia. It occurs in the freshwater of Bangladesh, Pakistan, Northern and Northeastern India and Nepal (Talwar and Jingran, 1991). Once, indigenous $M$. cuchia was abundant throughout the Bangladesh, plenty in mud holes in shallow "beels" and 'boro' paddy fields particularly in Sylhet, Mymensingh and Tangail Districts (Rahman, 1989). But presently this fish is hardly found in the open water bodies. The IUCN, Bangladesh (2000) enlisted M. cuchia as vulnerable species in the country. Improper water management policy for irrigation, over exploitation and various ecological changes in natural habitat; this species is threatened now (Diaster, 1990; Chakraborty and Nur, 2009). Considering the importance of this species in nutritional, economic and biodiversity point of view, the conservation and propagation are needed. Studies on the reproductive biology of the fish is essential for evaluating the conservation potentialities of its stock, life history, cultural practice and actual management of the fish (Lagler 1956; Doha and Hye

1World Fish Center, South East Asia Office, Dhaka, Bangladesh. 
1970). Reproductive potential of a population is one of the basic exigencies to designate the individuals of that population in respect to their gonadal conditions (Jhingran and Verma 1972). It is very important to assess the yearly breeding cycle of $M$. cuchia to make success in breeding practice. Knowledge of gonad development and the spawning season of a species allow subsequent studies on spawning frequency of its population, which is very important for its management. The present work was undertaken to find out the natural reproductive cycle of both sexes of $M$. cuchia based on Gonado Somatic Index (GSI). It was also decided to determine the fecundity of M. cuchia with a view to generate information on the basis of need of the fishery biologists and hatchery operators.

\section{MATERIAL AND METHODS}

The study was conducted at the Noukuchi rice field (beel), Noukuchi, Union of Kangsa, Jhenaigati, Sherpur, Bangladesh. Female gonads were collected from April to August 2010. Samples of Monopterus cuchia were collected from the experimental Noukuchi rice field. During the above period, 62 samples were collected to measure the total length and body weight of individual fish. Then the ovary of each fish was taken out very carefully and preserved in $10 \%$ buffered formalin for further study. The weight of the ovary was measured very carefully with the help of a sensitive portable electronic balance (Model HL 400 $\mathrm{EX)}$.

GSI of M. cuchia was calculated according to the formula of Lagler 1956:

GSI $=($ Gonad Weight $/$ Total weight $) \times 100$.

Von Vayer method was applied to estimate the fecundity of relatively large size eggs. In this method, the ovaries were dissected out by a pair of scissors. The external connective tissues were removed from the surface of each pair of ovaries. The moisture of the ovaries was removed with the help of a blotting paper. The weight of the ovaries of each fish was measured with the help of an electronic balance. Then $20 \mathrm{mg}$ of each ovary was taken separately from anterior, middle and posterior portions of each lobe accurately. The number of mature and maturing eggs from each portion was counted by a needle. The mean number of eggs (in $20 \mathrm{mg}$ ) was determined and then multiplied by the total weight of the ovary, to estimate the total number of eggs.

Statistical package MICROSTAT and EXCEL were used to determine correlation co-efficient ( $\mathrm{r}$ ) between total length and fecundity, body weight and fecundity, and gonadal weight and fecundity following the methods of Zar (1984). 


\section{RESULTS AND DISCUSION}

The ovary of $M$. cuchia bears a lobe which are connected along their dorsal surfaces by a thin mesentery from which they are suspended in the abdominal cavity. The lobe is elongated and found to be cylindrical size (Plate 1). The anterior parts of the ovary are more or less cylindrical.

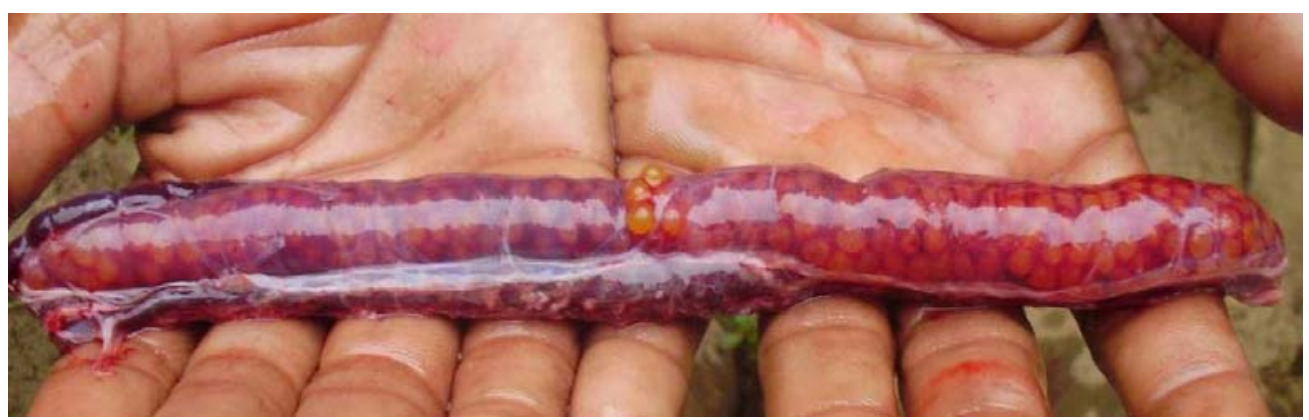

Plate 1. Collected ova of M. cuchia

Monthwise changes in mean GSI values of both males and females of $M$. cuchia are presented in Fig. 1 The mean GSI of the fish tends to increase as the fish reach maturity and after spawning, it declines and the minimum GSI was recorded during resting phase. In case of male $M$. cuchia, it has been found that the weight of the gonad gradually increased from January to July. It increased stage by stage slowly and reached to a maximum value $(6.62 \pm 0.35 \mathrm{~g})$ in June and July. Highest GSI value was found in the month of June and July, and the GSI values began to fall gently from August to December. But in case of female $M$. cuchia, the weight of the gonad gradually increased from January to June. It developed stage by stage slowly and reached to a maximum value $(48.62 \pm 2.66$ g) in June. Highest GSI value was found in the month of June and the GSI values began to fall gently from July to December. The GSI values for males and females were found to be from $0.40 \pm 0.01$ to $2.00 \pm 0.11$ and $1.99 \pm 0.03$ to 9.87 \pm 1.04 respectively and are presented in the Fig. 1

The relationship between fecundity and total length $(\mathrm{mm})$ is presented in Fig. 2 The relationship was found to be polynomial of second order of body weight and was expressed as: $\mathrm{Y}=0.2683 \mathrm{X}^{2}-1.9383 \mathrm{X}+370.72$. The equation yielded $\mathrm{R}^{2}=0.9473$ indicated that fecundity was highly $(\mathrm{P}<0.01)$ correlated with the total length of fish. Scatter diagram of fecundity and total body weight of $M$. cuchia has been shown in Fig. 2. The technique followed to establish the best mathematical relationship between fecundity and total body weight was presented in Table 1 . The regression equation of fecundity on total body weight was found to be represented by: $\mathrm{Y}=454.37 \mathrm{X}-692.8$. 


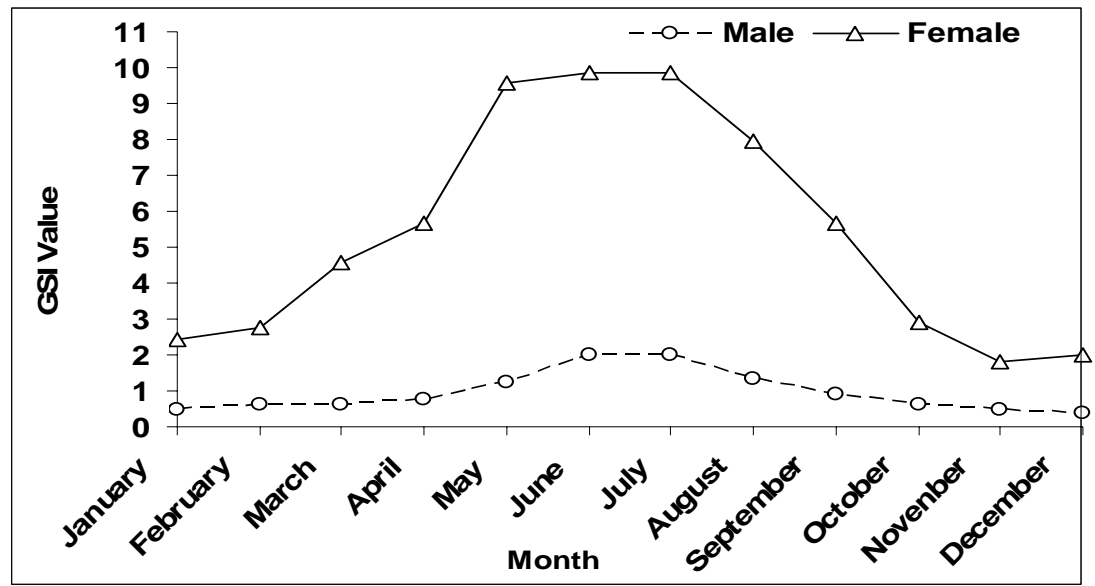

Fig. 1. Monthly mean value of gonado-somatic index (GSI) of male and female M. cuchi. (n=62)

Table 1. Number of eggs in relation to mean and standard deviation ( $\pm S D)$ of total length, mean body weight and mean gonad weight of Monopterus cuchia

\begin{tabular}{cccccc}
\hline $\begin{array}{c}\text { Group size in } \\
\text { length }(\mathrm{cm})\end{array}$ & $\begin{array}{c}\text { No. of fish } \\
\text { examined }\end{array}$ & $\begin{array}{c}\text { Mean total } \\
\text { length }(\mathrm{cm})\end{array}$ & $\begin{array}{c}\text { Mean body } \\
\text { weight }(\mathrm{g})\end{array}$ & $\begin{array}{c}\text { Mean ovary } \\
\text { weight }(\mathrm{g})\end{array}$ & $\begin{array}{c}\text { Mean } \\
\text { fecundity }\end{array}$ \\
\hline $50-55$ & 12 & $54.25 \pm 1.71$ & $256.33 \pm 45.14$ & $21.32 \pm 4.48$ & $458.0 \pm 31.22$ \\
$56-60$ & 21 & $58.67 \pm 1.23$ & $320.57 \pm 24.21$ & $34.12 \pm 3.78$ & $601.23 \pm 64.40$ \\
$61-65$ & 27 & $62.22 \pm 1.52$ & $364.63 \pm 51.25$ & $43.25 \pm 9.12$ & $785.22 \pm 92.31$ \\
$66-70$ & 2 & $66.05 \pm 0.71$ & $492.50 \pm 53.22$ & $55.90 \pm 0.98$ & $1116.0 \pm 11.31$ \\
\hline
\end{tabular}

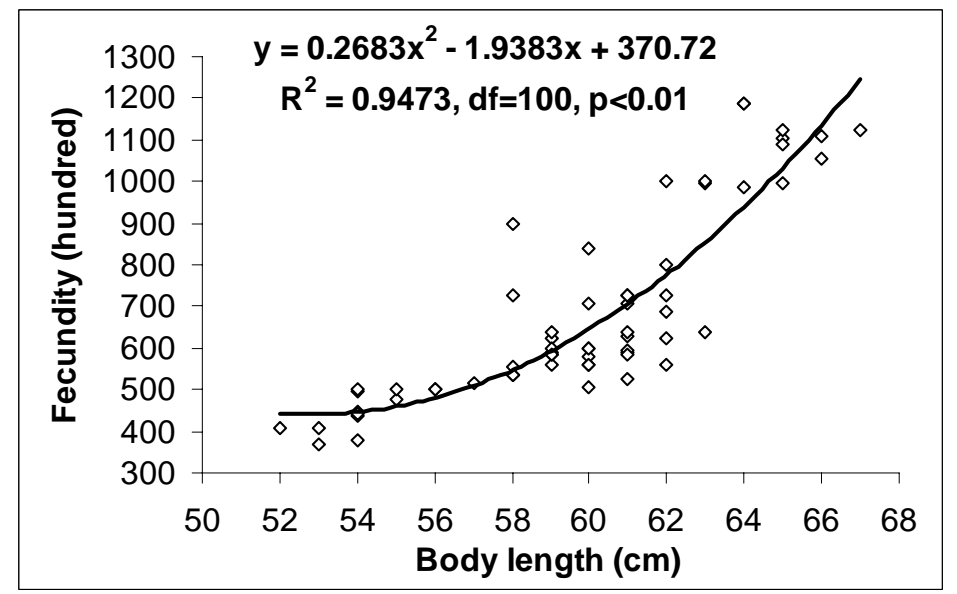

Fig. 2. Correlation coefficient $\left(\mathrm{R}^{2}\right)$ between fecundity and body length of M. cuchia 
Fig. 3 shows that the relationship between fecundity and total weight was curvilinear in nature. From the linear correlation value $\left(\mathrm{R}^{2}=0.6606\right)$, it was concluded that fecundity had high $(\mathrm{P}<0.01)$ correlation with the body weight of fish.

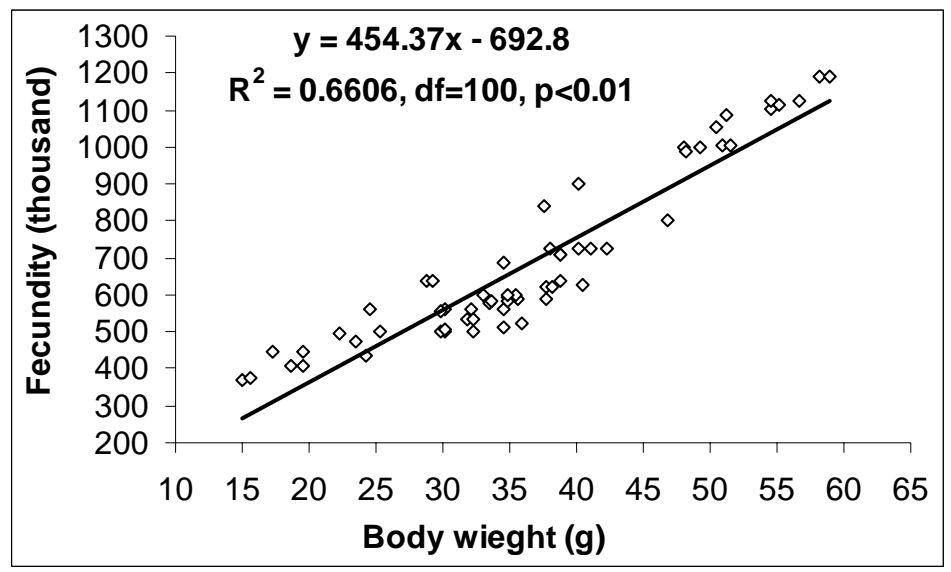

Fig. 3. Correlation coefficient $\left(\mathrm{R}^{2}\right)$ between fecundity and ovary weight of $M$. cuchia

Fig. 4 shows the scatter diagram of fecundity and gonadal weight relationship of $M$. cuchia. A highly $(\mathrm{P}<0.01)$ significant linear relationship was found to exist between fecundity and gonadal weight, where $\mathrm{R}^{2}=0.8793$ and the equation was $\mathrm{Y}=19.602 \mathrm{X}-27.546$. Similarly, fecundity had high $(\mathrm{P}<0.01)$ correlation with the ovary weight of fish.

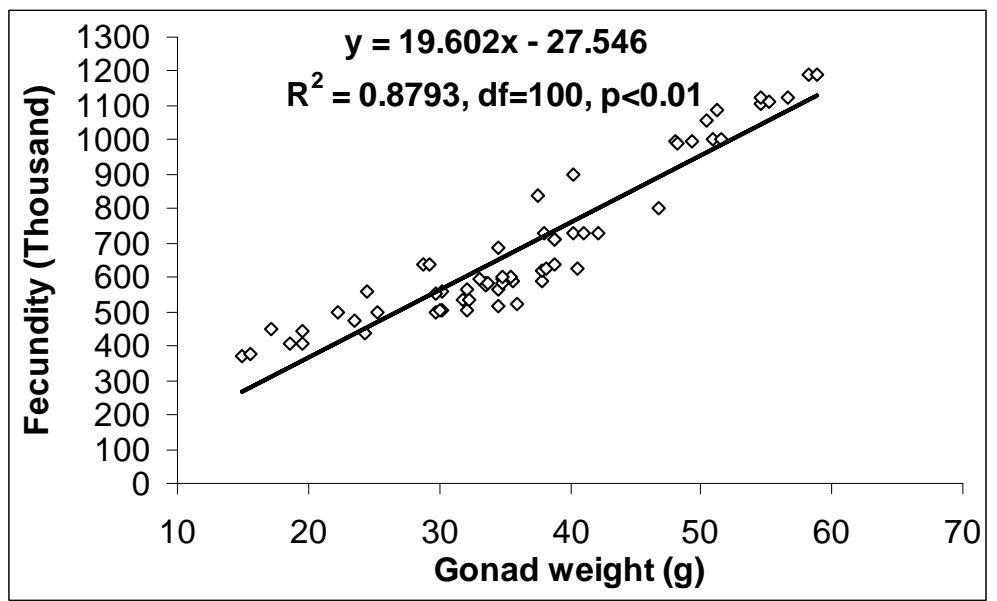

Fig. 4. Correlation coefficient $\left(\mathrm{R}^{2}\right)$ between fecundity and gonad weight of $M$. cuchia 
Reproductive cycle of indigenous $M$. cuchia was examined to observe the pattern and timing of growth phase and maturation stages of the gonad of male and female individuals. De Vlaming et al. (1982) discussed the utility of GSI as indicator of the reproductive activity of a stock. The GSI increases with the maturation of fish, being highest during the period of peak maturity and declining abruptly thereafter, when the fish become spent (Le Cren 1951). The monthly change of GSI reflects the ovarian activity of fish. The results of the present experiment indicated that the GSI of $M$. cuchia is highest during June when the fish was found to be mature. The increasing GSI of M. cuchia suggests that the percentage of yolk laden ripe eggs in ovary was found in June which was similar to Chakraborty (2010). He found the spawning period of chela (Chela phulo) between June and September. Reports on the fecundity of $M$. cuchia are very meagre. However, the fecundity of Barbus stigma observed by Dewan (1973) for a single female with a total length of $10 \mathrm{~cm}$ and a weight of $28.5 \mathrm{~g}$ was 14,569. Shafi and Quddus (1974) reported that the fecundity of P. stigma varied from 1242 to 6831. Mustafa et al., (1982) reported that the fecundity of $P$. sarana ranged from 18,925 to 78,925 from a beel in Tangail whereas, Sobhana and Nair (1974) recorded that fecundity of $P$. sarana ranged between 12,235 to 74,376 from a lake of Trivandrum, India.

From the present observation, it is clear that fecundity is directly proportional to total length and weight which is in conformity with the findings of Simpson (1951). The relationship between fecundity, body weight and gonad weight of M. cuchia was found to be curvilinear. Gupta (1968) also observed a linear relationship between fecundity and ovary weight which was similar to this study. But the relationship between fecundity and length of M. cuchia was found to be polynomial which is supported by Safi and Quddus, 1974; Sinha, 1975 and Chakraborty et al., 2005.

Lagler et al. (1967) reported that the number of eggs produced by an individual female was dependent on various factor like size, age and condition of the species. It was also observed in some cases that the fecundity of some larger fishes was much less than that of some smaller fish. This type of variation was also reported by Ahmed et al., 1979.

It is evident from the present study that Gonado Somatic Index (GSI) and fecundity is helpful to identify accurate spawning cycle of M. cuchia. The peak period of spawning season (May-July) of cuchia was identified from the study of GSI value. Identifying the spawning season cycle of cuchia, it would be restricted to catch this fish in the spawning period. At the same time the habitat of water body would be developed for spawning of cuchia. So, the production of cuchia 
would be increased. Further study would be required to apply the findings the field level.

Acknowledgements: The authors are gratefully acknowledge the financial support of World Fish Centre, Bangladesh and thankful to the department of Fisheries for kind support and cooperation.

\section{LETERATURE CITED}

AHMED, A.T.A., MUSTAFA, G. and HAI, A. 1979. Fecundity of cat fish, Clarias batrachus (L.). J. Asiatic Soc. (Bangladesh) Sci., 5(2): 7-12.

CHAKRABORTY B.K. 2010. Fecundity and Induction of spawning in spiny Guchi, Marognathus pancalus (Bloch \&Schneider, 1822) in Bangladesh Bangladesh J. Zool. 38(1): 77-91.

CHAKRABORTY B.K., MIAH M.I., MIRZA M.J.A. and HABIB M.A.B. 2005. Estimation of fecundity of endangered indigenous sarpunti, Puntius sarana. J. Bangladesh Agril. Univ. 3(1): 107-113.

CHAKRABORTY, B. K. and. NUR. N.N. 2009. Study on aquatic biodiversity of Medha Beel in the Northern Bangladesh. Journal of Crop and Weed, India, 5(2):4-11.

DEWAN, S. 1973. Investigation into the ecology of fishes of Mymensingh Lake. Ph.D. Dissertation. Bangladesh Agril. University Mymensingh, Bangladesh. 235 pp.

DEWAN, S. and DOHA S. 1979. Spawning and fecundity of certain pond fishes. Bangladesh J. Agric., 4(1): 1-8.

DE VLAMING, V., GROSSMAN, G. and CHAPMAN, F. 1982. On the use of the gonado-somatic index. Com. Biochemis. and Physiol. 73: 31-39.

DISASTER, E. (1990). Floodplain protection in Central Europe. World Wildlife Found (WWF) Institute of Floodplains Ecology Visiting Card 31/90, Germany.

DOHA, S. and HYE, M.A. 1970. Fecundity of Padma River hilsa, Hilsa ilisha (Ham.). Pakistan J. Sci., 22 (3 \& 4): 176-178.

GUPTA, M.V. 1968. Observations on the fecundity of Polynemus paradiseus (L.) from the Hoogly estuarine system. Proceeding of National Institute of Science, India (B), 34(6): 330-345.

JHINGRAN, A.G and VERMA, D.N. 1972. Sexual maturity and spawning of Gadusia chapra (Ham.) in Ganga river system. Proc. Nat. Sci. Acad. India, 42(2): 207-224.

IUCN, 2000. List of threatened animal of Bangladesh. Paper presented in the Workshop on Bangladesh Red Book of Threatened Animals. 22 Feb. 1998. Dhaka.13 p.

LAGLER, K.F. 1956. Freshwater Fishery Biology $2^{\text {nd }}$ ed., W. M. C. Brown Company, Bubuque, Lowa, UK. $541 \mathrm{pp}$.

LAGLER, K.F., BARDACH, J.E. and MILLER, A.R. 1967. Ichthylogy. John Wiley \& Sons. New York, USA. 545 pp.

LE CREN, E.D. 1951. 1951. The length-weight relationship and seasonal cycle in gonad weight and condition in perch. J. Anim. Ecol., 20: 201-219.

MUSTAFA, G. 1991. Composite culture and biology of some indigenous fishes of Bangladesh. Ph. D. Dissertation. Faculty of Biological Science, Dhaka University, Dhaka. 299 pp.

RAHMAN, A. K.A. 1989. Fresh water Fishes in Bangladesh, pp.263-264.

SHAFI, M. and QUDDUS, M.M.A. 1974. The fecundity of common punti, Puntius stigma (Cuv. \& Val.) (Cyprinidae: Cypriniformes). Bangladesh J. Zool., 2(2): 133-145. 
SINHA, M. 1975. Observation on the biology of Puntius sarana (Ham.) of Loni Reservoir (Madhya Pradesh). J. Inland Fish Soc., India, 7: 49-57.

SOBHANA, B and NAIR, N.B. 1974. Observation on the maturation and spawning of Puntius sarana (Val). India J. Fish., 21(2): 357-363.

TALWAR, P.K. and JHINGRAN, A.G. 1991. Inland fishes of India and adjacent countries. Vol. 2. Oxford and IBH Publishing, New Delhi, Bombay, Calcutta.

ZAR, J.H. 1984. Biostatistics. Prentice-Hall, Inc. Englewood Cliffs, New Jersey, USA. 718 pp.

(Manuscript received on 14 January 2013; revised on 10 November 2013) 